UDK: $159.923+[005.336: 37.091 .3]]: 001.891^{“ \ldots} \ldots / 2020 “$

Pregledni članak

Primljeno: 15. 7. 2020.

Prihvaćeno za štampu: 23. 11. 2020.

Mr. sc. Arijana Midžić, as.

Univerzitet u Bihaću

Islamski pedagoški fakultet

E-mail:arijana_91@windowslive.com

\title{
OSOBINE LIČNOSTI I OBRAZOVNI USPJEH: DOSEZI DOSADAŠNJIH ISTRAŽIVANJA
}

\section{Sažetek}

Obrazovno postignuce već nekoliko godina zaokuplja pažnju istraživača, što je rezultiralo velikim brojem istraživanja koja ispituju brojne faktore koji pridonose obrazounom $i$ akademskom postignuín učenika i studenata. Cilj rada je teorijska obrada pojmova osobina licnosti $i$ obrazovnog uspjeha, navodenje $i$ analiziranje dostupnih definicija $i$ uvid u pregled literature relevantnih autora koji su sa svojim radovima doprinijeli razumijevanju povezanosti $i$ predikcije osobina licnosti $s$ obrazounim, odnosno, akademskim uspjehom. U ovom preglednom radu iznesen je prikaz relevantnib naučnib radova, prikaz o mogucnostima objašnjavanja obrazovnog uspjeha ǚnika osnovne, srednje šoole i akademskog uspjeha studenata na temelju razlicitith osobina ličnosti. Prikazan je doprinos svake od razmatrane osobine licnosti u objašnjenju akademskog uspjeha. Prikazana dosadašnja istraživanja u ovom radu dala su odredene podatke koji govore u prilog pozitivne povezanosti i predikcije osobina ličnosti Petofaktorskog modela ličnosti i akademskog uspjeha.

Ključne riječi: obrazovni uspjeh, obrazovni neuspjeh i osobine ličnosti.

\section{Uvod}

Živimo u vremenu kada se velika važnost pridaje akademskom uspjehu i akademskom neuspjehu, kada postignuće izravno utiče na nastavak školovanja, odabira škole, zanimanja i na mogućnost odabira studija. U području psihologije, posebno njezinog dijela koji se bavi problemima 
obrazovanja, već godinama se nastoji utvrditi što veći broj varijabli koje bi mogle imati utjecaj na akademski uspjeh ili neuspijeh. Povećanje znanja o varijablama koje predviđaju akademski uspjeh ima važne implikacije za obrazovni sistem jer omogućuje nastavnicima da predvide koji će učenici / studenti imati uspjeh - bolji ili lošiji. U današnjem društvu akademsko postignuće je sve značajnije, a unatoč tome postignuće još uvijek nema jasne definicije. Postignuće kao pojam susrećemo još 1953. godine kada su Atkinson, Mek Klilendom i sar. (1953; prema Frančesko, Mihić i Kodžopeljić, 2002) stvorili instrument za mjerenje postignuća. Radi se o motivu postizanja kojim je ličnost vođena u određenoj aktivnosti. Danas je na Zapadu postalo uobičajeno da se postignuće identifikuje s akademskim uspjehom, a taj se pojam najčešće javlja kao sintagma ,akademsko postignuće“ $i$ to prvenstveno u kolokvijalnom govoru. Akademsko postignuće se javlja kao potreba ličnosti da pokaže integritet i demonstrira sposobnosti, kao potreba za pripadanjem i za ostvarivanjem poštovanja od strane drugih ljudi, dakle postignuće ima socijalnu dimenziju. Ranija istraživanja koja su sproveli autori Kalechstein i Nowicki (1997) provjeravala su doprinos kognitivnih i motivacijskih varijabli, osobina ličnosti, obilježja studija, porodična i socijalna okolina studenta, vještina, navika, te pristupa učenju u predviđanju akademskog (ne)uspjeha studenata. Najčešće povezivane individualne osobine $\mathrm{s}$ akademskim postignućem su inteligencija i osobine ličnosti.

Postignuće se obično operacionalizira kao uspjeh na standardiziranim testovima znanja. Najčešće korištene mjere akademskog postignuća su prosječna ocjena tokom studija, uspjeh na tačno određenom testu ili na standardiziranim testovima znanja (Kalechstein i Nowick, 1997). Ivić i Matešić (2009) navode da školski uspjeh ima važnu ulogu u životu pojedinca. Proučavanje mogućih faktora koji utječu na školski uspjeh u središtu je pozornosti brojnih istraživanja. Iako se različiti autori kao što su Gadžić i Milivojević (2009) ne slažu u pogledu krajnjeg određenja faktora školskog uspjeha, većina ih kao faktore uspješnosti navodi doprinose inteligencije i osobina ličnosti. Školski uspjeh (školsko postignuće) odnosi se na stepen ovladavanja učenika znanjima, intelektualnim i praktičnim vještinama, kognitivnim strategijama predviđenim programima različitih školskih disciplina. Uspjeh izražen školskim ocjenama je jedan pokazatelj usvojenog 
znanja, percepcije vlastite ličnosti učenika, faktor dalje obrazovne promocije, socijalnog ponašanja i cjelokupnog ponašanja djeteta.

Školski uspjeh se može definisati i kao uspjeh u nastavi koji je nastavnom djelatnošću postignuti nivo realizacije materijalnih, formalnih i odgojnih zadataka nastave, specifikovanih nastavnim programom, tj. stepen u kojem su učenici trajno usvojili nastavnim programom propisana znanja, vještine i navike, razvili svoje psihofizičke sposobnosti i formirali moralno saznavanje, htijenje i djelovanje (Markovac, 1973). Pojam akademsko postignuće podrazumijeva savlađivanje programa koji predstavlja uslov za školsku prolaznost, sticanje diplome ili akademskog zvanja. Akademsko postignuće se najčešće verifikuje školskom ocjenom, diplomom, certifikatom ili nekim drugim vidom oficijelne potvrde o savlađivanju datog programa obuke. Pojam školsko učenje nije potpuno podudaran s pojmom akademsko postignuće zato što se u tom učenju ne može sve verifikovati i iskazati oficijelnom mjerom postignuća. Kada govorimo o akademskom postignuću, govorimo o nastojanju učenika da ostvari što bolje ocjene, da što brže i efikasnije dođe do diplome, da napreduje u struci i osvaja titule. Dakle, govorimo o vanjskim motivima, o potrebi čovjeka da se socijalno promoviše i da ostvari zvanično priznati napredak (Suzić, 2005).

Jedna od najčešćih definicija ličnosti koju su dali Larsen i Buss (2005) kaže da je ličnost skup organiziranih, razmjerno trajnih psiholoških osobina i mehanizama unutar pojedinca koji utječu na njegove interakcije s okolinom i prilagođavanje na okolinu. John, Angeleintner i Ostendorf (1988) navode da se trajni obrasci ponašanja i doživljavanja osobe mogu predvidjeti iz njezinih osobina ličnosti. Razvoj petofaktorskog modela je usko vezan s istraživanjem leksičke hipoteze. Također, autori u svom djelu navode da je početnu hipotezu postavio Francis Galton (1884, prema John, Angeleintner i Ostendorf 1988), a Goldberg (1992) je dao njezinu najpoznatiju definiciju: „One individualne razlike koje su najistaknutije i socijalno relevantne u životima ljudi će postati kodirane u njihovom jeziku. Što je neka razlika važnija, to je vjerovatnije da će biti izražena zasebnom riječju.“

Prema Johnu (1990) polazna tačka istraživanja leksičke hipoteze je ekstrakcija i analiza svih pojmova relevantnih za ličnost, a koji se nalaze $\mathrm{u}$ rječniku. Da bi taksonomija bila korisna mora pružiti 
sistematični okvir za razlikovanje, razvrstavanje i imenovanje individualnih razlika u ljudskom ponašanju $\mathrm{i}$ iskustvu.

Faktori koje su našli Tupes i Christal (1961) kasnije su nazvani „Big five“ ili „Velikih pet“", kako bi se naglasilo da svaki od njih predstavlja široku dimenziju i obuhvaća velik broj specifičnih i odvojenih karakteristika ličnosti. Najprihvaćeniji nazivi faktora su: Ekstraverzija, Ugodnost, Savjesnost, Neuroticizam i Otvorenost (faktori su poredani po veličini). Ekstraverzija se odnosi na pristup socijalnom svijetu. Ekstraverti su osobe koje postižu visok rezultat na ovom faktoru, a opisuju ih pridjevi poput društveni, asertivni, razgovorljivi, energični, optimistični i imaju visoku potrebu za stimulacijom. Osobe koje postižu niske skorove na ovom faktoru se opisuje kao introverte, povučene, mirne, nezavisne i vole samoću. Digman (1990) navodi da se Ekstraverzija prije svega odnosi na socijabilnost i društvenost.

Ugodnost se također odnosi na interpersonalnu orijentaciju. Karakteristični pridjevi su: ljubazan, povjerljiv, prijateljski, blag i sl. Suprotan pol ove dimenzije je antagonizam, a uključuje karakteristike poput nepovjerljivosti, tvrdoglavosti, grubosti i nekooperativnosti. Ugodnost se obično smatra poželjnom i adaptivnom, ali i antagonizam je u određenoj mjeri nužan za svakodnevno funkcioniranje. Ekstremno visoka ili niska Ugodnost može upućivati i na neprilagođeno ponašanje i patologiju. Ugodnost je dimenzija interpersonalnih relacija i uključuje povjerenje, altruizam, saosećajnost, potrebu da se pomogne drugima, nasuprot je cinizmu, sebičnosti i antagonizmu, sumnjičavosti u pogledu namjera drugih ljudi, egocentričnosti i kompetitivnosti. Uži aspekti su povjerenje, iskrenost, altruizam, predusretljivost, skromnost, blaga narav.

Savjesnost se ponegdje naziva i Snaga volje, Usmjerenost ili Želja za životom. Taj faktor opisuje čestice koje se odnose na ponašanja orijentirana na zadatak, slijeđenje pravila i normi, planiranje, organiziranje te prepoznavanje prioriteta. Savjesne osobe su usmjerene na zadatak, dobro organizirane, samodisciplinirane, tačne, pouzdane i svrhovite. Njihova suprotnost su osobe koje postižu niske rezultate na ovom faktoru, a opisuje ih se kao neodgovorne, površne, nepouzdane, neorganizirane i lijene (McCrae i Costa, 1987). Savjesnost predstavlja sposobnost samokontrole u smislu disciplinovane težnje ka ciljevima i striktno pridržavanje sopstvenih principa. Ispoljava se u procesima 
planiranja, organizacije, izvršenja dužnosti i obaveza. Savjesne osobe su jake volje usmjerene ka cilju, skrupulozne, tačne i pouzdane (Digman, 1990).

McCrae i Costa (1987) navode da Neuroticizam označava sklonost proživljavanju psihološkog stresa, te kognitivnim i bihevioralnim stilovima koji proizlaze iz te sklonosti. Neurotične osobe doživljavaju kronične negativne emocije poput ljutnje, tuge, krivnje i straha, imaju slabu kontrolu impulsa i sklone su razvoju raznih psihijatrijskih poremećaja. Osobe koje postižu visok rezultat na skali Neuroticizma su napete, nesigurne, anksiozne i nestrpljive, za razliku od emocionalno stabilnih, mirnih, opuštenih i strpljivih osoba čiji rezultat na ovoj skali je nizak. Prema Digmanu (1990) Neuroticizam je prvi domen koji razlikuje prilagođenost $i$ emocionalnu stabilnost $u$ odnosu na neprilagođenost i emocionalnu nestabilnost. Neuroticizam je opšta tendencija ka doživljavanju negativnih afekata kao što su tuga, strah, uznemirenost, gnjev, krivica i druga negativna osjećanja. Sklonost doživljavanju ovakvih emocija predstavlja opštu vulnerabilnost i ometa adaptaciju zbog čega su osobe s visokim skorom na skali Neuroticizma sklone razvoju različitih mentalnih poremećaja.

Otvorenost je faktor oko kojeg se autori najmanje slažu. Poštovaoci leksičkog pristupa kao što je John (1990) ga nazivaju Intelektom. Costa i McCrae (1987) koriste naziv Otvorenost iskustvima, smatrajući da se radi o široj dimenziji, nego što pretpostavljaju poštovaoci leksičkog pristupa. McCrae i John (1992) navode da se povremeno javljaju i nazivi Inteligencija i Kultura. Ovaj faktor obuhvaća kreativnost, intelektualni i umjetnički interes, potrebu za promjenama i nekonvencionalnim vrijednostima. Visok rezultat na ovoj skali označava znatiželjne, maštovite, nekonvencionalne osobe, okrenute novim socijalnim, etičkim i političkim idejama. Suprotno tome, nizak rezultat upućuje na osobe sklone konvencionalnom ponašanju, uskih interesa, konzervativnih pogleda na svijet i tome slično. Digman (1990) pod Otvorenošću podrazumijeva estetsku senzitivnost, intelektualnu radoznalost, preferenciju različitosti, potrebu za promjenom i nezavisnost mišljenja, odnosno sklonost nedogmatičnim stvarima. Ovakve osobe su otvorenog duha prema unutrašnjim doživljavanjima i radoznale prema spoljnim događajima. Osobe sa niskim skorovima na skali Otvorenosti su konvencionalnog izgleda i ponašanja, sklone 
konzervativnim stavovima, preferiraju poznato $\mathrm{u}$ odnosu na novo, emocionalne reakcije su im umjerenije, a interesovanja sužena. Uži aspekti ovog domena su otvorenost ka fantaziji, estetici, osjećanjima, akciji, idejama i vrijednostima.

\section{Dosezi dosadašnjih istraživanja}

Istraživanja akademskog postignuća već nekoliko desetljeća zaokupljaju pažnju psihologa, odgajatelja, roditelja i studenata. Definicije akademskog postignuća određuju taj pojam kao „specificiranu razinu uspjeha ili dostignuća evaluiranog od strane učitelja, standardiziranog testa ili kao njihova kombinacija“. Veliki broj istraživanja i dugogodišnje proučavanje ovog područja rezultirali su identificiranjem faktora koji doprinose akademskom uspjehu u visokoj školskoj edukaciji, ali i onih koji su povezani s neuspjehom (Chaplin, 1975).

U ovom dijelu rada obuhvaćeno je devet naučnih radova i tri longitudinalne studije koji objašnjavaju odnos, odnosno povezanost osobina ličnosti i akademskog postignuća. Iz pregleda dosadašnjih istraživanja, najveći broj njih je rađen u SAD-u i Velikoj Britaniji, a manji broj na području Evrope. Iz dostupnih elektronskih baza, iz kojih su pretraživana istraživanja dobijene su informacije da pored SAD-a i Velike Britanije ima naučnih radova i iz Estonije, Hrvatske, Irana, Španije, ali ne i iz Bosne i Hercegovine.

Postoje mnogobrojna relevantna istraživanja koja su se bavila provjeravanjem doprinosa kognitivnih i motivacijskih varijabli, osobinama ličnosti, obilježjima studija, porodičnom te socijalnom okolinom studenta, vještinama, navikama i pristupima učenju u predviđanju akademskog (ne)uspjeha studenata, a jedno od tih istraživanja je i od autora Kalechstein i Nowicki (1997).

Za potrebe ovog rada kroz pregled relevantnih dosadašnjih istraživanja bit će predstavljeni samo radovi koji se odnose na osobine ličnosti i obrazovni uspjeh. Istraživanja koja su navedena u nastavku ovog rada sprovedena su na temu prediktivne moći osobina ličnosti, odnosno koliko osobine ličnosti objašnjavaju varijablu akademsko postignuće i povezanost ovih varijabli. U pregledu ranijih istraživanja želi se ukazati na odnos osobina ličnosti i akademskog postignuća uvidom u 
istraživanja koja su sprovedena na učenicima osnovnoškolskog i srednjoškolskog uzrasta i studentima.

Istraživanje koje su realizirali Busato i sar. (1999) na uzorku od N=900 studenata upućuju na to da su i kognitivne sposobnosti i osobine ličnosti važni prediktori akademskog uspjeha jer je ustanovljeno da su oboje povezani s učenjem.

Ivić i Matešić (2009) su sproveli istraživanje u kojem je sudjelovalo 178 učenika 3. i 4. razreda gimnazije u dobi od 17 do 19 godina. Za ispitivanje osobina ličnosti primijenjen je Big Five upitnik (Big Five Questionnaire), a inteligencija je mjerena testom Domino 2000 (D2000). Kao mjera školskog uspjeha korišten je opći uspjeh učenika (prosjek ocjena) na kraju školske i godine i ocjene iz grupe društvenih i prirodnih predmeta. Analiza korelacija je pokazala da je dimenzija Savjesnost, uključujući i obje njezine poddimenzije (Temeljitost i Ustrajnost), statistički značajno povezana sa školskim uspjehom. Regresijskom je analizom utvrđeno da glavne dimenzije ličnosti i inteligencija zajedno objašnjavaju 17,9\% varijance općeg školskog uspjeha pri čemu od osobina ličnosti osobina Savjesnost ima najveći doprinos. Ovi rezultati upućuju na to da određene osobine ličnosti iz modela „Velikih pet“ mogu pridonijeti objašnjenju varijacije školskog uspjeha. Za kriterij grupe društvenih predmeta poddimenzija Ustrajnost je pokazala veću značajnost od poddimenzije Temeljitost. Otvorenost prema iskustvu se pokazala kao relativno manje povezana s kriterijima školskog uspjeha od druge poddimenzije. Otvorenost prema kulturi je najznačajnija i gotovo identična općoj crti mentalne otvorenosti pri objašnjavanju povezanosti $\mathrm{s}$ uspjehom u grupi društvenih predmeta. Dimenzija Energije nije povezana $\mathrm{s}$ kriterijem grupe društvenih predmeta, a s općim uspjehom i grupom prirodnih predmeta je povezanost relativno niska. Međutim, zanimljivo je da poddimenzija Dominacija pokazuje značajniju i veću povezanost s grupom prirodnih predmeta i općim uspjehom, te nešto manje značajnu povezanost $\mathrm{s}$ grupom društvenih predmeta. Ovi rezultati upućuju na to da bi poddimenzija Dominacija bila relativno bolji prediktor od opće dimenzije Energije. Zbog malog uzorka u ovom istraživanju, bilo bi dobro ponoviti takvu analizu na većem broju ispitanika. Jedno od objašnjenja različitih rezultata istraživanja u pogledu varijable Energije 
možda leži u različitosti konstrukcije ove dimenzije u instrumentima temeljenim na modelu ,Velikih pet.“

Autori Robbins i sar. (2004) su u svojoj studiji ispitivali odnos psihosocijalnih i faktora vještina učenja i rezultata na fakultetu metaanalizom 109 studija. Studija je pokazala da je Savjesnost najvažniji prediktor akademskog uspjeha.

Furnham i Chamorro-Premuzic (2003) su radili istraživanje s britanskim studentima, a sudjelovao je ukupno $\mathrm{N}=91$ student (74 Ž i $17 \mathrm{M}$ ). U svom istraživanju autori su došli do rezultata koji su pokazali da se pozitivna povezanost Ekstraverzije i akademskog uspjeha u osnovnoj školi mijenja u negativnu povezanost između ovih varijabli u srednjoj školi i na fakultetu. Također, podaci do kojih su došli pokazuju da Ugodnost kao dimenzija ličnosti nije prediktivna za akademski uspjeh, dok ostale dimenzije ličnosti petofaktoroskog modela ličnosti imaju prediktivnu moć.

Sanchez-Marin i sar. (2001) su na ukupno 103 učenika prosječne dobi od 21 godine uz korištenje upitnika $16 \mathrm{PF}$, Ankete o međuljudskim vrijednostima (SIV), uključujući procjenu inteligencije pomoću Wechslerovog testa inteligencije, došli do rezultata u kojima navode da su introverti manje distraktibilni, da bolje utvrđuju naučeno i imaju bolje navike učenja od ekstraverata koji puno više vremena provode $u$ socijalnim aktivnostima. Autori su došli do zaključka da se to posebno očituje na višim stepenima obrazovanja, kao što je fakultetsko obrazovanje gdje je atmosfera kompetitivnija i formalnija od one na nižim stepenima obrazovanja kao što su osnovna i srednja škola.

Laidra, Pullmann i Allik (2007) su sproveli istraživanje na velikom uzorku N=3618 (1746 dječaka i 1872 djevojčice) estonskih školaraca od osnovne do srednje škole, iz cijele Estonije koji pohađaju 2. 3. 4. 6. 8. i 10. razred. Ukupno 12 razreda je sudjelovalo u ovoj studiji. Inteligencija je mjerena Ravenovim standardnim progresivnim matricama, osobine ličnosti su mjerene sa „Big Five“ za djecu 2. i 4. razreda i NEO-PI-R za djecu od 6. do 12. razreda. Rezultati su pokazali da su Otvorenost, Susretljivost i Savjesnost korelirali pozitivno, a Neuroticizam je negativno korelirao sa školskim uspjehom u gotovo svim razredima. 
Wagerman i Funder (2007) su na uzorku preddiplomskog studija $(\mathrm{N}=131)$ istraživali Savjesnost i procjenu Savjesti korištenjem Big Five Inventory (BFI) i dobili su rezultate koji pokazuju da je Savjesnost čvrsto povezana $\mathrm{s}$ akademskim postignućima i kod brucoša i kod starijih studenata. Dakle, dimenzija Savjesnost korelira s uspjehom na svim akademskim godinama studija i u kontekstu ličnosti je valjan i jedinstven prediktor uspjeha. Naprimjer, u nekim instrumentima kao što su NEO-PI-R (Costa i Mc Crae, 1985) i MASQ (Pintrich i De Groot, 1995) pojedinci koji postižu visoke rezultate na ovoj dimenziji su opisani kao društveno poželjni, socijalizirani (pozitivna konotacija) ili socijalno dominantni (negativna konotacija). Stoga je moguće da se i te različite pretpostavke odnose različito na školski uspjeh.

Matthews i sar. (2000) navode da je između Neuroticizma i akademskog uspjeha utvrđena negativna povezanost, koja se najčešće tumači anksioznošću i stresnim uvjetima kao što su ispitivanja u školi. Prema ovim autorima Neuroticizam se povezuje i s neredovitim dolaženjem na nastavu, odgađanjem izvršavanja školskih obaveza, te negativnim simptomima kao što su lupanje srca, znojenje, gastrološke smetnje i mišićna napetost koji mogu doprinijeti lošem akademskom uspjehu.

Hakimi i sar. (2011) su sproveli istraživanje u kojem je sudjelovalo 285 učenika (191 Ž i $94 \mathrm{M}$ ). Korišteni su instrumenti NEO-PI-R i postignuće studenata. Rezultati su otkrili da su osobine ličnosti značajno povezane s akademskim postignućem. Regresijska analiza je pokazala da su osobine ličnosti studenata bihevioralnih nauka objasnili $48 \%$ varijance akademskog postignuća. Ipak, uzevši u obzir isključivo razinu visokog obrazovanja, meta-analize upućuju na Savjesnost kao jedini relevantan prediktor akademskog postignuća.

Prema Eccles i sar. (1993) u sveobuhvatnoj longitudinalnoj studiji, koja obuhvata učenike osnovne škole, navodi se da neurotični učenici teže odolijevaju nekim impulsima što djeluje negativno na disciplinu pri učenju, što se može povezati s nekim facetama faktora Savjesnosti (npr. samodisciplina). Kod takvih učenika motivacija za uspjeh u školi opada u funkciji dobi. Autori, također, navode da je Otvorenost ka iskustvu povezana s uspjehom u školi i na fakultetu, i to na dodiplomskom i postdiplomskom studiju. Ova povezanost se često objašnjava time što ova osobina ličnosti korelira $\mathrm{s}$ kristaliziranom inteligencijom. 
Otvorenost ka iskustvu nije pokazala dosljednu prediktivnu vrijednost za akademski uspjeh u svim istraživanjima. O značajnoj povezanosti između faktora Ugodnosti i akademskog uspjeha ne postoje empirijski dokazi. Nije utvrđena niti povezanost između Ugodnosti i inteligencije.

Chamorro-Premuzic i Furnham (2003) su sproveli dvije longitudinalne studije na dva britanska sveučilišna uzorka. Akademski uspjeh ocjenjivao se kroz razdoblje od tri godine i na više kriterija (npr. ispiti i završni projekt). Pored toga, ispitano je i nekoliko pokazatelja akademskog ponašanja, npr. izostanci, pisanje eseja, predviđanja rezultata za ispite kako u pogledu akademske uspješnosti, tako i osobina ličnosti pomoću „Velikih pet“. Na 1. uzorku (N=70) su utvrdili da Neuroticizam i Savjesnost predviđaju ukupne ocjene završnog ispita, koji čine više od $10 \%$ jedinstvene varijance u ukupnom broju ispita. Rezultati sugeriraju da Neuroticizam može oslabiti akademsku uspješnost, dok Savjesnost može dovesti do većih akademskih postignuća. U 2. uzorku (N=75) kao mjerilo ličnosti korišten je EPQ-R (Eysenck i Eysenck, 1985), a rezultati su pokazali da su tri superfaktora najmoćniji prediktor akademskog učinka, čineći gotovo 17\% jedinstvene varijance u ukupnim rezultatima ispita. Dokazano je da (poput Neuroticizma) Psihotizam može ograničiti akademski uspjeh. Rezultati pružaju dokaze koji podržavaju uključivanje dobro utvrđenih mjera ličnosti u postupke akademskog odabira.

Navedeni autori ranijih relevantnih istraživanja naglašavaju da su osobine ličnosti važan faktor u previđanju i objašnjavanju akademskog postignuća. Iz ovog pregleda jasno je kako bi se boljim upoznavanjem osobina ličnosti mogle predvidjeti one osobe koje su u opasnosti od neuspjeha, uz uvažavanje pojedinačnih karakteristika i individualizirani pristup. U skladu s navedenim pregledom dosadašnjih istraživanja zaključuje se da je najzastupljeniji dizajn istraživanja onaj koji je orijentisan na varijable i slučajeve, odnosno studije koje uključuju veliki i mali broj slučajeva i opservacioni dizajn. U pregledu istraživanja nije zastupljen eksperimentalni dizajn koji se odnosi na eksperimentalnu i kontrolnu grupu i izolaciju efekta jedne nezavisne varijable na zavisnu varijablu. 


\section{Zaključak}

Teorijski značaj rada ogleda se u dobijanju sumiranih informacija o ranijim istraživanjima koja su sprovedena u svijetu i Evropi, i informacijama o tome kakva je i kolika povezanost između osobina ličnosti i akademskog uspjeha. Dat je cjelovit prikaz o radovima $\mathrm{u}$ kojima su objavljene naučne informacije, naučne spoznaje, koje su sintetizirane i naučno prezentirane. Praktični značaj rada odnosi se na mogućnost potencijalnih radova u okviru ekperimentalnog dizajna, s obzirom da ovaj dizajn nije zastupljen u dosadašnjim istraživanjima. Pregledi ranijih istraživanja daju podatke o tome da kognitivne sposobnosti omogućavaju učenje i razumijevanje pogotovo na višem stepenu obrazovanja, a da od osobina ličnosti Savjesnost vrijedi kao najbolji prediktor akademskog uspjeha na svim nivoima obrazovanja, što nije slučaj s osobinom ličnosti Ugodnost. Za ovu dimenziju ne postoje empirijski podaci koji potvrđivanju njene prediktivne moći. Ekstraverzija i Otvorenost ka iskustvu su prediktori akademskog postignuća na svim nivoima obrazovanja, dok se Neuroticizam nalazi u negativnoj povezanosti s akademskim uspjehom i uglavnom se dovodi u vezu sa stresnim situacijama koje podrazumijevaju ispitivanja u školi. Kako je cilj rada povećavanje interesa za razmatranje i uvažavanje rezultata ranijih istraživanja i provođenje novih, preporuke ovog rada jesu buduća istraživanja koja mogu doprinijeti ovom cilju. Kako je riječ o relativno malom broju istraživanja, od kojih su sva opservacijska (prosječna istraživanja), odnosno istraživanja koja uključuju mali broj slučajeva, preporuke za buduća istraživanja su usmjerene na prevazilaženje spomenutih ograničenja, te da se urade longitudinalne $\mathrm{i}$ eksperimentalne studije u koje bi se uključio i pristup učenju $u$ predviđanju akademskog (ne)uspjeha učenika i studenata na području Bosne i Hercegovine.

\section{Literatura}

1. Busato, V. V., Prins, F. J., Elshout, J. J. i Hamaker, C. (1999) The relation between learning styles, the Big Five personality traits and achievement motivation in higher education. Personality and Individual Differences, 26, 129-140. 
2. Chamorro-Premuzic, T. i Furnham, A. (2003) Personality predicts academic performance: Evidence from two longitudinal university samples. Journal of Research in Personality, 37, 319-338.

3. Chaplin, J. P. (1975) Dictionary of psychology. New York: Dell. Revised edition.

4. Costa, P.T. i McCrae, R.R. (1985) Cross-sectional studies of personality in a national sample, Psychology and again, 1, 140-143.

5. Digman, J. M. (1990) Personality Structure: Emergence of the FiveFactor Model, Annual Review of Psychology, 4, 417440.

6. Eccles, J. S., Wigfield, A., Midgley, C., Reuman, D., Mac Iver, D. i Feldlaufer, H. (1993) Negative effects of traditional middle schools on student's motivation. The Elementary School Journal, 93(5), 553-574.

7. Eysenck, H. J. i Eysenck, M. W. (1985) Personality and individual diferences. New York: Plenum.

8. Furnham, A. i Chamorro-Premuzic, T. (2003) Personality and intelligence as predictors of statistics examination grades, Personality and Individual Differences, 37, 943-957.

9. Frančesko M., Mihić V. i Kodžopeljić J. (2002) Neki socio-demografski i psihološki korelati postignuća. Vol 35 (1-2), 65-79.

10. Gadžić, A. i Milivojević, A. (2009) Školski uspeh i status adolescenata u razredu. Teme, 33 (4), 1379-1389.

11. Goldberg, L. R. (1992) The development of markers for the Big-Five factor structure. Journal of Personality and Social Psychology. 59, 1216-1229.

12. Hakimi, S., Hejazi, E. i Lavasani, M. G. (2011) The Relationships Between Personality Traits and Students' Academic Achievement. Procedia - Social and Behavioral Sciences, 29, 836-845.

13. Ivić, J. i Matešić, K. (2009. Povezanost inteligencije i nekih osobina ličnosti iz modela „Velikih pet” sa školskim uspjehom u završnim razredima srednje škole. Pedagogijska istraživanja, 6 (1-2), 91-101.

14. John, O. P., Angleitner, A. i Ostendorf, F. (1988) The lexical approach to personality: A historical review of trait taxonomic research. European Journal of Personality, 2, 171203.

15. John, O. P. (1990) The „Big Five“ factor taxonomy: Dimensions of personality in the natural language and questionnaires. In L. A. Pervin (Ur.) Handbook of personality: Theory and research (66-100) New York: Guilford Press.

16. Kalechstein, A. D. i Nowicki, Jr. S. (1997) A meta-analytic examination of the relationship between control expectancies and academic 
achievement: An 11-yr follow-up to Findley and Cooper. Genetic, Social, and General Psychology Monographs, 123, 27-56.

17. Laidra, K., Pullmann, H. i Allik, J. (2007) Personality and intelligence as predictors of academic achievement: A cross - sectional study from elementary to secondary school. Personality and Individual Differences, $42,441-451$.

18. Larsen, R. J. i Buss, D. M. (2005) Introduction to personality. In Personality psychology: Domains of knowledge about human nature (2nd ed., 1-23). Boston: McGraw-Hill.

19. Markovac, J. (1973) Suzbijanje neuspeha u osnovnoj školi. Beograd: Jugoslovenski zavod za proučavanje školskih i prosvetnih pitanja.

20. Matthews, M. D., Pleban, R. J., Endsley, M. R. i Strater, L.G. (2000) Measures of infantry situation awareness for a virtual MOUT environment. Proceedings of the Human Performance, Situation Awareness and Automation: User-Centered Design for the New Millennium. Savannah, GA: SA Technologies, Inc.

21. McCrae, R. R. i Costa, P. T. (1987) Validation of the five-factor model of personality across instruments and observers. Journal of Personality and Social Psychology, 52, 81-90.

22. McCrae, R. R. i John, O. P. (1992) An introduction to the five-factor model and its applications. Journal of Personality, 60, 175-215.

23. Pintrich, P.R. i De Groot, E.V. (1990) Motivational and self-regulated learning components of classroom academic performance. Journal of. Educational Psychology 82 (1), 33-40.

24. Robbins, S. B., Lauver, K., Le, H., Davis, D., Langley, R. i Carlstrom, A. (2004) Do Psychosocial and Study Skill Factors Predict College Outcomes? A Meta-Analysis. Psychological Bulletin, 130, 261-288.

25. Sanchez-Marin, M., Rejano-Infante, E. i Rodriguez-Troyano, Y. (2001) Personality and academic productivity in university student, Journal of Social Behaviour and Personality, 29, 299-306.

26. Suzić, N. (2005) Motivacija za akademsko postignućem. Podgorica: Vaspitanje i obrazovanje za pedagošku teoriju i praksu.

27. Tupes, E. C. i Christal, R. E. (1961) Recurrent Personality Factors based on Trait Ratings. USAF ASD Tech. Rep. No. 61-97, Lackland Airforce Base, TX: US Air Force.

28. Wagerman, S. A. i Funder, D. C. (2007) Acquaintance reports of personality and academic achievement: A case for conscientiousness. Journal of Research in Personality, 41, 221-229. 
mr. sci. Arijana Midžić, assistant

University of Bihać

Islamic Pedagogical Faculty

Email:ari_jana_91@windowslive.com

\section{PERSONALITY FEATURES AND EDUCATIONAL SUCCESS: ACHIEVEMENTS OF RECENT RESEARCH}

\section{Abstract}

Educational achievement has been catching the attention of researchers for several years, resulting in a large body of research examining a number of factors that contribute to the educational and academic achievement of students. The aim of this paper is to theoretically analyze the concepts of personality traits and educational success, to list and analyze the available definitions and to review the literature of relevant authors who have contributed to the understanding of the connection and prediction of personality traits with educational or academic success. In this review paper, an overview of relevant scientific papers is presented, an account of the possibilities of explaining the educational success of elementary school students, high school students, and the academic achievement of students based on differentpersonality traits. The contribution of each of the considered personality traits in explaining academic success is presented. The research presented so far in this paper has provided some data that support the positive correlation of personality trait prediction of the Five-factor model of personality and academic success.

Keywords: educational success, educational failure and personality traits. 


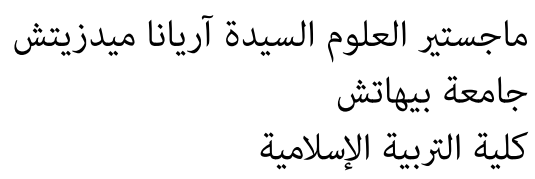

E-mail:arijana_91@windowslive.com

\section{ميزات الشخصية والنجاح التعليمي: إنجازات البحوث الأخيرة}

\section{الخلاصة}

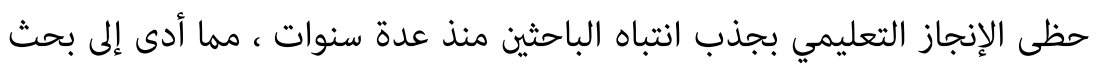

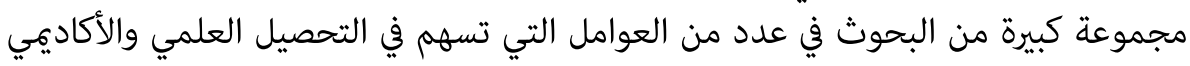

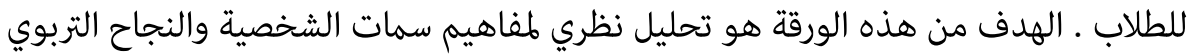

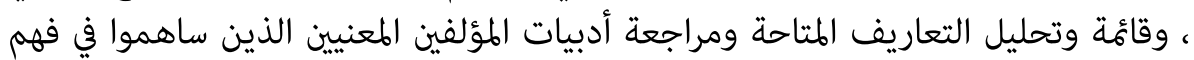

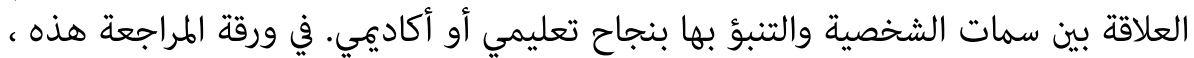

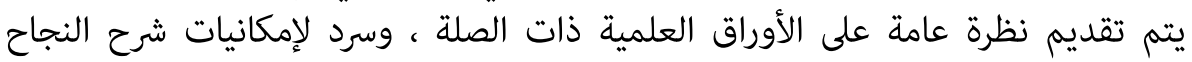

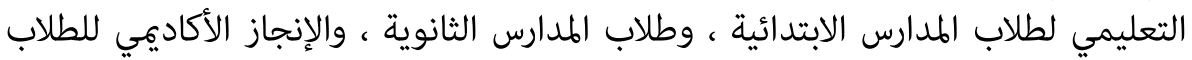

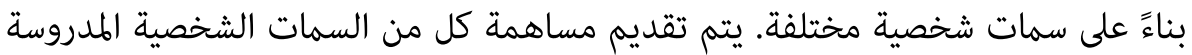

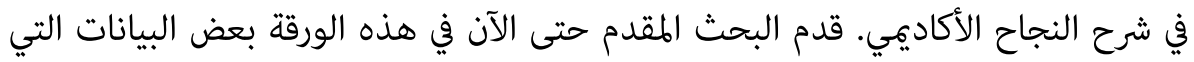

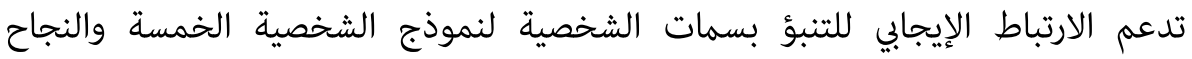

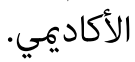

لكلمات المفتاحية: النجاح التربوي ، الفشل التربوي وسمات الشخصية. 